\title{
Importance of Coastal Change Variables in Determining Vulnerability to Sea- and Lake-Level Change
}

\author{
Elizabeth A. Pendleton, E. Robert Thieler, and S. Jeffress Williams
}

U.S. Geological Survey

Woods Hole Science Center

384 Woods Hole Road

Woods Hole, MA 02543 U.S.A.

ependleton@usgs.gov

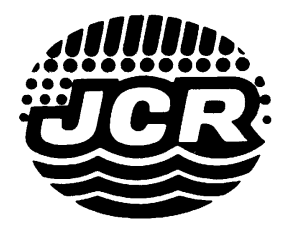

\begin{abstract}
PENDLETON, E.A.; THIELER, E.R., and WILLIAMS, S.J., 2010. Importance of coastal change variables in determining vulnerability to sea- and lake-level change. Journal of Coastal Research, 26(1), 176-183. West Palm Beach
\end{abstract} (Florida), ISSN 0749-0208.

\begin{abstract}
In 2001, the U.S. Geological Survey began conducting scientific assessments of coastal vulnerability to potential future sea- and lake-level changes in 22 National Park Service sea- and lakeshore units. Coastal park units chosen for the assessment included a variety of geological and physical settings along the U.S. Atlantic, Pacific, Gulf of Mexico, Gulf of Alaska, Caribbean, and Great Lakes shorelines. This research is motivated by the need to understand and anticipate coastal changes caused by accelerating sea-level rise, as well as lake-level changes caused by climate change, over the next century. The goal of these assessments is to provide information that can be used to make long-term (decade to century) management decisions. Here we analyze the results of coastal vulnerability assessments for several coastal national park units.

Index-based assessments quantify the likelihood that physical changes may occur based on analysis of the following variables: tidal range, ice cover, wave height, coastal slope, historical shoreline change rate, geomorphology, and historical rate of relative sea- or lake-level change. This approach seeks to combine a coastal system's susceptibility to change with its natural ability to adapt to changing environmental conditions, and it provides a measure of the system's potential vulnerability to the effects of sea- or lake-level change. Assessments for 22 park units are combined to evaluate relationships among the variables used to derive the index. Results indicate that Atlantic and Gulf of Mexico parks have the highest vulnerability rankings relative to other park regions. A principal component analysis reveals that $99 \%$ of the index variability can be explained by four variables: geomorphology, regional coastal slope, water-level change rate, and mean significant wave height. Tidal range, ice cover, and historical shoreline change are not as important when the index is evaluated at large spatial scales (thousands of kilometers).
\end{abstract}

ADDITIONAL INDEX WORDS: Shoreline change, geomorphology, tidal range, mean annual ice cover, mean significant wave height, relative sea-level rise, lake-level change, coastal slope, coastal vulnerability index, National Park Service, Great Lakes.

\section{INTRODUCTION}

Recent projections of global sea-level rise (SLR) and lakelevel fluctuations due to climate-induced changes have generated an interest in coastal science to determine the response of coastlines to sea- and lake-level change. A primary challenge in understanding shoreline response to water-level change is quantifying the important variables that contribute to coastal evolution in a given area.

Published analyses of tide gauge data suggest a 20th-century mean rate of global SLR to be between 1.5 and $2.0 \mathrm{~mm} / \mathrm{y}$, with most estimates falling around $1.8 \mathrm{mma}^{-1}$ (Church et al., 2001, 2004; Douglas, 1997; Miller and Douglas, 2004; Peltier, 2001). Climate models predict a future global SLR of $0.25-$ $0.5 \mathrm{~m}$ by 2100 , which for several carbon emission scenarios is more than double the SLR rate for the 20th century (Church et al., 2001; Meehl et al., 2007). Global SLR estimates from TOPEX/Poseidon and Jason-1 satellite altimeters sug-

DOI: $10.2112 / 08-1102.1$ received 31 October 2008; accepted in revision 4 November 2008. gest that SLR rates since 1993 may be near $3 \mathrm{mma}^{-1}$ (Cazenave and Nerem, 2004; Leuliette, Nerem, and Mitchum, 2004), which resembles predicted SLR acceleration estimates for the 21st century published by the Intergovernmental Panel on Climate Change (2001, 2007). A study by Rahmstorf et al. (2007) suggests that the SLR rates published by this panel may be conservative, and sea level by 2100 may be between 0.5 and $1.4 \mathrm{~m}$ higher than in 1990 (Rahmstorf, 2007). The exact rates of present and future global SLR are uncertain. The potential impacts of SLR include coastal erosion, increased storm-surge flooding, saltwater intrusion into groundwater aquifers, inundation of wetlands, and threats to cultural and historical resources, as well as infrastructure (Church et al., 2001; FitzGerald et al., 2008; Meehl et al., 2007; Nicholls et al., 2007).

Based on results of global climate models, the Great Lakes region is expected to experience warmer and drier climate conditions into the 21 st century, which are predicted to result in a drop in lake levels (only one model, HadCM2, suggests that lake levels may rise; U.S. Global Change Research Program, 2000). Throughout the 1900s, lake levels in the Great 
Table 1. National Park Service units in the vulnerability assessment project. Mean relative sea- and lake-level change rates are from Zervas (2001) and Croley, Hunter, and Martin (2001), respectively.

\begin{tabular}{|c|c|c|}
\hline National Park Service Units & $\begin{array}{l}\text { State or } \\
\text { Territory }\end{array}$ & $\begin{array}{c}\text { Mean Relative } \\
\text { Sea- or Lake-Level } \\
\text { Change Rate } \\
(\mathrm{mm} / \mathrm{y}) \dagger\end{array}$ \\
\hline Apostle Islands National Lakeshore & Wisconsin & 0.40 \\
\hline $\begin{array}{l}\text { Assateague Island National Sea- } \\
\text { shore }\end{array}$ & $\begin{array}{l}\text { Maryland, } \\
\text { Virginia }\end{array}$ & 3.26 \\
\hline Cape Cod National Seashore & Massachusetts & 2.62 \\
\hline Cape Hatteras National Seashore & North Carolina & 3.71 \\
\hline Channel Islands National Park & California & 2.74 \\
\hline $\begin{array}{l}\text { Cumberland Island National Sea- } \\
\text { shore }\end{array}$ & Georgia & 2.04 \\
\hline Dry Tortugas National Park & Florida & 2.27 \\
\hline Fire Island National Seashore & New York & 2.70 \\
\hline Gateway National Recreation Area & $\begin{array}{l}\text { New York, } \\
\text { New Jersey }\end{array}$ & 3.21 \\
\hline $\begin{array}{l}\text { Glacier Bay National Park and Pre- } \\
\text { serve }\end{array}$ & Alaska & -5.68 \\
\hline $\begin{array}{l}\text { Golden Gate National Recreation } \\
\text { Area }\end{array}$ & California & 2.16 \\
\hline Gulf Islands National Seashore $\ddagger$ & $\begin{array}{l}\text { Florida, } \\
\quad \text { Mississippi }\end{array}$ & 2.43 \\
\hline Indiana Dunes National Lakeshore & Indiana & 4.00 \\
\hline $\begin{array}{l}\text { Kaloko-Honokohau National Histor- } \\
\text { ical Park }\end{array}$ & Hawaii & 3.36 \\
\hline Kenai Fjords National Park & Alaska & -1.46 \\
\hline National Park of American Samoa & $\begin{array}{l}\text { American } \\
\text { Samoa }\end{array}$ & 1.48 \\
\hline Olympic National Park & Washington & -1.19 \\
\hline Padre Island National Seashore & Texas & 3.44 \\
\hline Point Reyes National Seashore & California & 2.51 \\
\hline $\begin{array}{l}\text { Sleeping Bear Dunes National } \\
\text { Lakeshore }\end{array}$ & Michigan & 4.00 \\
\hline Virgin Islands National Park & St. John & 0.50 \\
\hline $\begin{array}{l}\text { War in the Pacific National Histori- } \\
\text { cal Park }\end{array}$ & Guam & 0.10 \\
\hline
\end{tabular}

$\dagger$ Positive values indicate water-level rise; negative values indicate waterlevel fall.

\$The Gulf Islands National Seashore is indicated in both Florida and Mississippi in Figure 1.

Lakes generally increased, with the 1970 s and 1980s producing record highs. Currently, however, lake levels are lower and appear to be nearing the long-term average (Croley, Hunter, and Martin, 2001). Recent studies by Assel, Quinn, and Sellinger (2004) and Austin and Colman (2007) showed that the drop in lake levels (since 1998) is the largest since the Dust Bowl of the 1930s and is likely a result of higherthan-average air temperatures over the Great Lakes. Potential coastal impacts of relative lake- or sea-level fall include dewatering and water quality reduction in wetlands and estuaries, decreases in harborage areas, channel shoaling, increased dredging needs, subaerial exposure of polluted marine sediments, gullying and erosion near rivers and streams associated with base-level changes, grounding of tidewater glaciers, and habitat loss.

The National Park Service (NPS) is responsible for managing nearly $12,000 \mathrm{~km}$ of shoreline along U.S. oceans and lakes. In 2001, the U.S. Geological Survey (USGS), in partnership with the NPS Geologic Resources Division, began conducting coastal vulnerability assessments of future sea-

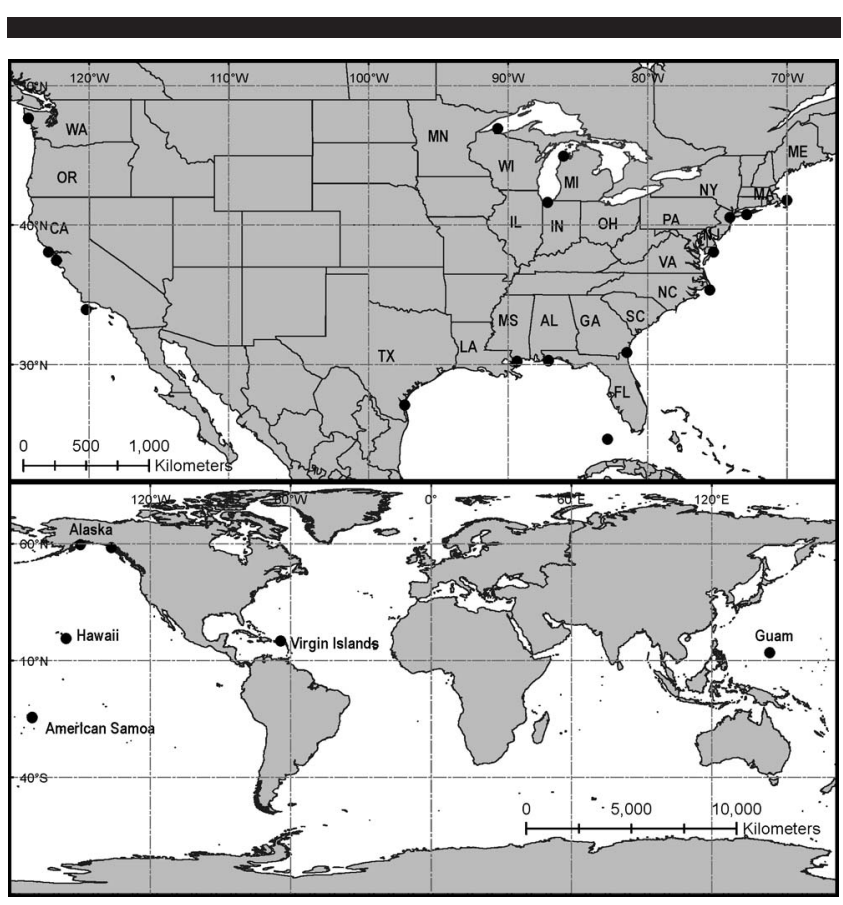

Figure 1. Map of U.S. National Park Service units included in the coastal vulnerability study (listed in Table 1), indicated by black filled circles. The island parks are located on Guam, American Samoa, the U.S. Virgin Islands, Dry Tortugas, and Hawaii. The other park regions are designated by the closest major body of water (e.g., Gulf of Alaska, Gulf of Mexico, Great Lakes). Gulf Islands National Seashore is indicated in both Florida and Mississippi (two filled circles).

level change by developing information to assist the NPS in managing its coastal resources. Twenty-two parks were selected by the NPS for the cooperative study (Table 1 and Figure 1; individual park reports may be obtained from the USGS, Woods Hole Science Center, 2005). To cover a variety of coastal environments in the United States, national park units were selected along the Great Lakes, Gulf of Mexico, Atlantic, and Pacific coasts of the contiguous United States, as well as the coasts of Alaska, Hawaii, Guam, American Samoa, and the U.S. Virgin Islands (Figure 1; Pendleton, Thieler, and Williams, 2005a, 2005b, 2007; Pendleton, Williams, and Thieler, 2003; Pendleton et al., 2003).

Results from 22 coastal vulnerability index (CVI) assessments are presented here. These park CVI assessments are used as a subset of natural coastal environments in the United States and its territories. Assessment data are used to classify areas that may be most likely to experience physical change in the next 50 to 100 years as sea- and lake-levels change and to demonstrate which characteristics of a coast may be most important to determining coastal vulnerability.

\section{METHODS}

The CVI methodology used here is the same as that used in Thieler and Hammar-Klose (1999) and is similar to that used by Gornitz et al. (1994), as well as to the sensitivity index employed by Shaw et al. (1998). One notable difference between this study and previous index assessments is that 
Table 2. Ranges from 1 to 5 for vulnerability ranking of variables for a variety of U.S. coasts.

\begin{tabular}{|c|c|c|c|c|c|c|}
\hline Variable & Region & Very Low (1) & Low (2) & Moderate (3) & High (4) & Very High (5) \\
\hline Geomorphology & All & $\begin{array}{l}\text { Rocky clif- } \\
\text { fed coasts, } \\
\text { fjords }\end{array}$ & $\begin{array}{l}\text { Medium cliffs, } \\
\text { indented } \\
\text { coasts }\end{array}$ & $\begin{array}{l}\text { Low cliffs, gla- } \\
\text { cial drift, al- } \\
\text { luvial plains }\end{array}$ & $\begin{array}{l}\text { Cobble beach- } \\
\text { es, estuary, } \\
\text { lagoon }\end{array}$ & $\begin{array}{l}\text { Barrier beaches, sand beaches, } \\
\text { salt marsh, mud flats, deltas, } \\
\text { mangrove, coral reefs }\end{array}$ \\
\hline Shoreline change $(\mathrm{m} / \mathrm{y})$ & All & $>2.0$ & 1.0 to 2.0 & -1.0 to 1.0 & -2.0 to -1.0 & $<-2.0$ \\
\hline \multirow[t]{2}{*}{$\begin{array}{l}\text { Regional coastal slope } \\
\quad(\%)\end{array}$} & $\begin{array}{l}\text { Atlantic, Gulf of } \\
\text { Mexico, Great } \\
\text { Lakes }\end{array}$ & $>1.2$ & 1.2 to 0.9 & 0.9 to 0.6 & 0.6 to 0.3 & $<0.3$ \\
\hline & $\begin{array}{l}\text { Pacific, Gulf of } \\
\text { Alaska, oceanic } \\
\text { islands }\end{array}$ & $>14.7$ & 10.9 to 14.69 & 7.75 to 10.89 & 4.6 to 7.74 & $<4.59$ \\
\hline \multirow{2}{*}{$\begin{array}{l}\text { Relative sea- or lake- } \\
\text { level change rate } \\
(\mathrm{mm} / \mathrm{y})\end{array}$} & All oceans & $<|1.8|$ & $\mid 1.81$ to $2.5 \mid$ & $\mid 2.51$ to $3.0 \mid$ & $\mid 3.01$ to $3.4 \mid$ & $>|3.4|$ \\
\hline & Great Lakes & 0 & 0.1 to 3.0 & 3.1 to 6.0 & 6.1 to 9.0 & $>9.1$ \\
\hline \multirow[t]{2}{*}{ Mean wave height (m) } & $\begin{array}{l}\text { Atlantic, Gulf of } \\
\text { Mexico, Great } \\
\text { Lakes }\end{array}$ & $<0.55$ & 0.55 to 0.85 & 0.86 to 1.05 & 1.06 to 1.25 & $>1.25$ \\
\hline & $\begin{array}{l}\text { Pacific, Gulf of } \\
\text { Alaska, oceanic } \\
\text { islands }\end{array}$ & $<1.1$ & 1.1 to 2.0 & 2.01 to 2.25 & 2.26 to 2.6 & $>2.6$ \\
\hline Mean tide range $(\mathrm{m})$ & All oceans & $>6.0$ & 4.0 to 6.0 & 2.0 to 4.0 & 1.0 to 2.0 & $<1.0$ \\
\hline $\begin{array}{l}\text { Mean annual ice cover } \\
\quad \text { (days) }\end{array}$ & Great Lakes & $>135$ & 106 to 135 & 61 to 105 & 30 to 60 & $<30$ \\
\hline
\end{tabular}

both submerging (experiencing relative water-level rise) and emerging (experiencing relative water-level fall) coastlines were assessed. The CVI is amenable to application in any coastal setting because, regardless of whether water level is rising or falling, the factors that are important to coastal change and shoreline evolution are typically the same. This method broadly characterizes the coast using simple criteria and yields numerical data that cannot be equated directly with particular physical effects. It does, however, highlight areas where the various effects of water-level change may be the greatest.

The CVI describes a range of vulnerability (low to very high) to assess a coast's potential susceptibility to physical change as sea or lake level changes. The index focuses on six variables that strongly influence coastal evolution: geomorphology, historical shoreline change rate, regional coastal slope, relative sea-level change, mean significant wave height, and mean tidal range (for the Great Lakes, mean annual ice cover was used in place of mean tidal range). These variables were selected to describe the physical characteristics of the coast and the physical processes that affect the coast over human timescales. The geological variables of geomorphology, historical shoreline change rate, and coastal slope account for a shoreline's relative resistance to erosion, its long-term erosion and accretion trend, and its susceptibility to flooding, respectively. The physical process variables (sea- or lake-level change, significant wave height, and tidal range, or mean annual ice cover for the Great Lakes) contribute to the inundation hazards along a coastline. A relatively simple ranking system (Table 2 ) allows the six variables, quantitative and qualitative, to be incorporated into an equation that produces an index.

The quantitative variables are divided into quintiles by re- gion and assigned a ranking based on their values, whereas the nonnumerical geomorphology variable is ranked qualitatively according to the relative resistance of a given landform to erosion. Shorelines with erosion-accretion rates between -1.0 and $+1.0 \mathrm{~m} / \mathrm{y}$ are ranked as moderate. Regional coastal slope ranges for the Pacific, oceanic islands, and Gulf of Alaska parks are ranked such that percent slopes less than $4.59 \%$ are very high vulnerability and greater than $14.70 \%$ are very low vulnerability (Table 2 ). Regional coastal slope ranges along the Atlantic, Gulf of Mexico, and Great Lakes are ranked with lower percent slope values, where a very high vulnerability is less than $0.3 \%$ and a very low vulnerability is greater than $1.2 \%$. The rate of relative sea-level change is ranked using the long-term global rate of eustatic rise $(1.8 \mathrm{~mm} / \mathrm{y})$ as the very low vulnerability. Since this is a global or "background" rate common to all shorelines, the sealevel ranking reflects primarily local to regional isostatic or tectonic adjustment. Water-level changes for the Great Lakes are ranked starting from zero because global SLR does not affect lake levels. Mean significant wave height rankings for the Pacific, Gulf of Alaska, and oceanic island parks range from less than $1.1 \mathrm{~m}$ to more than $2.6 \mathrm{~m}$., whereas Atlantic, Gulf of Mexico, and Great Lakes parks have wave height rankings from less than 0.55 to more than $1.25 \mathrm{~m}$. Tidal range is ranked such that microtidal $(<1 \mathrm{~m})$ coasts are very high and macrotidal $(>6 \mathrm{~m})$ coasts are very low. Because the Great Lakes are essentially nontidal, mean annual ice cover in days was selected as a useful variable contributing to coastal change on the Great Lakes (Pendleton, Thieler, and Williams, 2007). Ice cover over decadal timescales is considered a protective agent in reducing storm erosion along the shoreline (Forbes et al., 2004).

Park assessments were conducted and stored with a geo- 
Table 3. Park shoreline length, percentage of total shoreline, mean of index values, and median of variable values for each park region.

\begin{tabular}{lrccc}
\hline \hline \multicolumn{1}{c}{ Region } & $\begin{array}{c}\text { Shoreline } \\
(\mathrm{km})\end{array}$ & $\begin{array}{c}\text { Total } \\
\text { Assessed } \\
\text { Shoreline }(\%)\end{array}$ & $\begin{array}{c}\text { Mean of } \\
\text { Index } \\
\text { Values }\end{array}$ & $\begin{array}{c}\text { Median of } \\
\text { Ranked } \\
\text { Variables }\end{array}$ \\
\hline Atlantic & 447 & 10 & 24.6 & 4 \\
Great Lakes & 382 & 9 & 9.0 & 3 \\
Gulf of Alaska & 2521 & 56 & 4.9 & 2 \\
Gulf of Mexico & 290 & 7 & 20.7 & 4 \\
Oceanic islands & 136 & 3 & 7.4 & 3 \\
Pacific & 660 & 15 & 8.7 & 3 \\
All parks combined & 4436 & 100 & 7.8 & 3 \\
\hline
\end{tabular}

graphic information system by appending data to $1: 24,000$ to $1: 80,000$-scale vector shorelines of a park. Park shorelines were divided into segments using a 1-minute grid, and a zonal statistics function was used to assign variable values and rankings (Table 2) as attributes to each segment of the park shoreline. After all variables and rankings were assigned for each shoreline segment, an index was calculated by taking the square root of the product of the ranked variables divided by the total number of variables

$$
\mathrm{CVI}=\sqrt{\frac{a \cdot b \cdot c \cdot d \cdot e \cdot f}{6}}
$$

where $a$ is the geomorphology, $b$ is the shoreline erosionaccretion rate, $c$ is the coastal slope, $d$ is the relative SLR rate, $e$ is the mean significant wave height, and $f$ is the mean tide range or mean annual ice cover. Coastal vulnerability was evaluated based on index values and ranked variables for all parks combined, as well as for the following geographic regions: Atlantic coast, Great Lakes, Gulf of Alaska, Gulf of Mexico, oceanic islands, and Pacific coast (Table 3).

Shoreline length, range of index values, and median ranked variable value for all parks in each region are shown in Figure 2 and Table 3. These data summaries are used to determine what percentage of total evaluated shoreline was represented in each region, whether there is a pattern or cor-

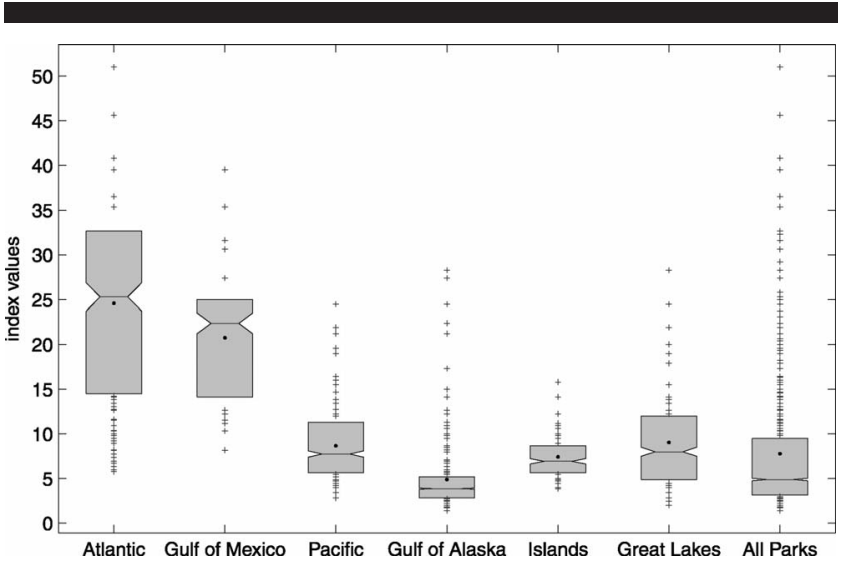

Figure 2. A box plot of index values for all regions and parks combined. The notched line is the median, and the shaded box represents the inner quartiles for each park region and for all parks. Pluses are index values outside the inner quartile range, and solid circles are the mean index value.

relation associated with indices and regions, and whether the median ranked variable value corresponds to vulnerability.

The variables defining the index are not independent or random; therefore, they do not contribute equally to the unweighted index. A principal component analysis is used to reduce the dimensionality of the assessment data, illustrate the relationships that exist among variables, and identify the relative importance of each variable. This analysis is performed on the covariance matrix of the index, calculated such that five variables are held at the mean and one variable is allowed to change. This isolates individual variables and returns the contribution of each variable within a principal component. Eigenvectors and principal component loadings, which are coefficients of the equation that defines the eigenvector and corresponds to a variable, are used to determine which variable or combination of variables is most influential to the index value and which variables are least influential (Table 4).

Table 4. Principal component analysis summary of the covariance matrix of coastal variables for all parks, including eigenvalues, percentage of variance explained, and coefficients of the principal components (loadings).

\begin{tabular}{|c|c|c|c|c|c|c|}
\hline Principal Component & Eigenvalue & $\begin{array}{l}\text { Variance Explained } \\
(\%)\end{array}$ & $\begin{array}{l}\text { Total Variance } \\
\text { (cumulative \%) }\end{array}$ & & & \\
\hline 1 & 12.37 & 52.47 & 52.47 & & & \\
\hline 2 & 5.85 & 24.82 & 77.29 & & & \\
\hline 3 & 3.55 & 15.06 & 92.35 & & & \\
\hline 4 & 1.71 & 7.27 & 99.62 & & & \\
\hline 5 & 0.09 & 0.37 & 99.99 & & & \\
\hline \multirow[t]{2}{*}{6} & Approximately 0 & Approximately 0 & 100.0 & & & \\
\hline & \multicolumn{6}{|c|}{ Principal Component } \\
\hline Variable & 1 & 2 & 3 & 4 & 5 & 6 \\
\hline Geomorphology & -0.091 & 0.4244 & -0.2385 & 0.8674 & 0.0486 & 0.0017 \\
\hline Shoreline change & 0.0317 & 0.1834 & 0.0135 & -0.0306 & -0.9166 & -0.3522 \\
\hline Coastal slope & 0.3053 & -0.3892 & 0.7508 & 0.4326 & -0.0652 & -0.0144 \\
\hline Sea-level rise & -0.7903 & -0.562 & -0.0825 & 0.1756 & -0.1078 & -0.1016 \\
\hline Wave height & 0.5213 & -0.5635 & -0.6094 & 0.1678 & -0.0853 & -0.0624 \\
\hline Tidal range or ice & 0.0346 & 0.0366 & 0.0328 & -0.024 & 0.3664 & -0.9282 \\
\hline
\end{tabular}




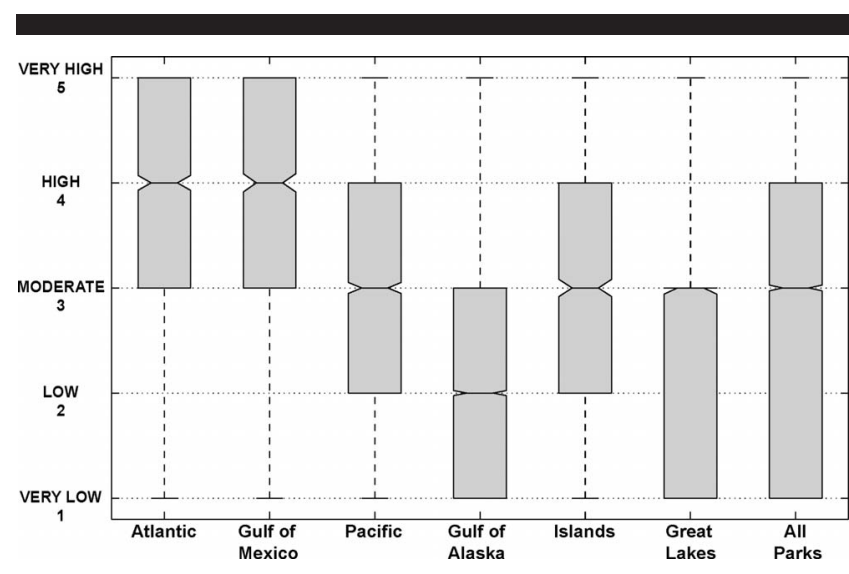

Figure 3. Box plot showing the range of ranked variables used to determine the index. The median value is indicated by the notch in each box. The whiskers extend to the range of the data. Here the median value for all variables is used as a proxy for overall vulnerability to coastal change. The Atlantic and Gulf of Mexico parks are ranked as high vulnerability; the Pacific, Island, and Great Lakes parks are moderate vulnerability; the Gulf of Alaska parks are low vulnerability.

\section{RESULTS}

Assessments of 22 national park units provide a comprehensive database of geological and physical characteristics for more than $4400 \mathrm{~km}$ of shoreline (Table 3). The park database is described here in terms of the regional differences between variables and index values and the relative importance of variables.

\section{Variables and Index Values in Park Regions}

The Gulf of Alaska parks have the largest quantity of evaluated shoreline, approximately $2500 \mathrm{~km}$, and represent more than $50 \%$ of the total assessed shoreline (Table 3). The oceanic island parks gave the smallest percentage of evaluated shoreline, representing 3\% of the total. The Gulf of Mexico, Great Lakes, Atlantic coast, and Pacific coast parks represented 7, 9, 10 , and $15 \%$ of total evaluated shoreline, respectively.

The Gulf of Alaska parks have the lowest mean and median index values. Atlantic and Gulf of Mexico coasts have the highest index values, whereas the Pacific coast parks have lower index values than other parks in the contiguous United States (Figure 2). The oceanic island parks have index values most similar to Pacific coast parks (Figure 2). The Great Lakes parks have a wide range of index values, but the mean value is closest to the Pacific and oceanic island parks (Figure $2)$. The large percentage of shoreline in the Alaska parks is evident in the box plot of indices for all parks (Figure 2). The median and mean of index values for the Atlantic and Gulf of Mexico parks plot are outliers in the "all parks" plot, because greater than $50 \%$ of the evaluated shoreline is in Alas$\mathrm{ka}$, where the mean index is 4.9 (Table 3 ).

Based on the median variable value for each region, the Atlantic and Gulf of Mexico park regions have the highest median variable values (high). The Alaska parks have the lowest median variable value (low). The Pacific, oceanic island, Great Lakes parks, and all parks combined have the same median variable value (moderate; Figure 3 ).

\section{Principal Component Analysis}

The first four principal components explain more than 99\% of the total variance among the variables for all parks (Figure 4A). The first two principal components account for more than $75 \%$ of the total variance and have the highest principal component loadings $(>0.4)$ among water level, wave height, slope, and geomorphology (Figures 4 and 5). The first principal component accounts for $52 \%$ of the total variance and identifies coasts where water-level rankings are high and wave and slope rankings are low (or vice versa). The second principal component accounts for $25 \%$ of the total variance and identifies coasts where the geomorphology ranking is low and water-level, wave height, and slope rankings are high (or vice versa). The third principal component accounts for $15 \%$ of the total variance and identifies coasts with high slope rankings and low wave height and geomorphology rankings (Figure 4B). Shoreline change and tidal range or ice cover rankings do not have loadings greater than 0.19 in the first four principal components (Figure 5).

An index based on the four variables with the highest loadings (geomorphology, coastal slope, water-level change rate, and wave height) in the first four principal components is calculated to highlight the small contribution of shoreline change and tidal range (or ice cover for the Great Lakes) and is compared to the original (six variable) index (Figures 6A and $6 \mathrm{~B})$. The four-variable index predicts approximately $93 \%$ of the variance that exists in the six-variable index. The mean normalized difference in the four-variable index and the six-variable index is 0.18 , or approximately $2 \%$.

\section{DISCUSSION}

Twenty-two national park coastal vulnerability assessments provide a foundation to evaluate regional differences in CVI statistics, geological and physical process variables, and relative vulnerability to sea-level change for more than $4400 \mathrm{~km}$ of shoreline (Table 3). A comparison of statistical results indicates that Atlantic and Gulf of Mexico parks have the highest vulnerability rankings relative to other park regions when index ranges and median variable values are used as a proxy for relative vulnerability. Pacific, Great Lakes, and oceanic island parks may be considered moderately vulnerable, whereas the Gulf of Alaska parks have the lowest mean index value and thus low relative vulnerability when compared to other park regions in this study. The difference between the Atlantic and Gulf of Mexico vulnerability and the Gulf of Alaska vulnerability to sea-level change is the physical differences in coastal characteristics represented in the geological variables of the Atlantic, Gulf of Mexico, and Gulf of Alaska. The park coastlines along the Gulf of Alaska tend to be steep and rocky, whereas Atlantic coast and Gulf of Mexico parks are generally low lying and sandy. Oceanic island, Pacific, and Great Lakes parks often represent more of a blend of the end-member coastal characteristics from the Gulf of Mexico, Atlantic, and Gulf of Alaska.

All variables that are incorporated into the index assessment can be considered factors contributing to coastal change; however, some variables make a larger contribution to index variability than others. A principal component analysis iden- 
A

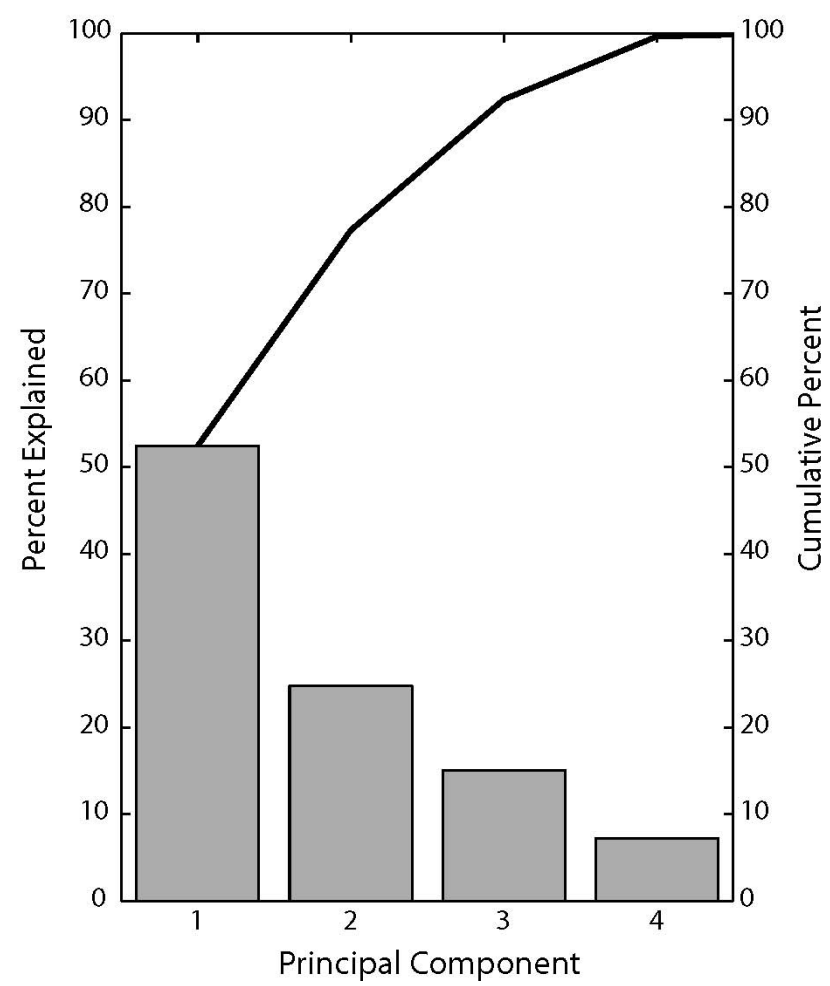

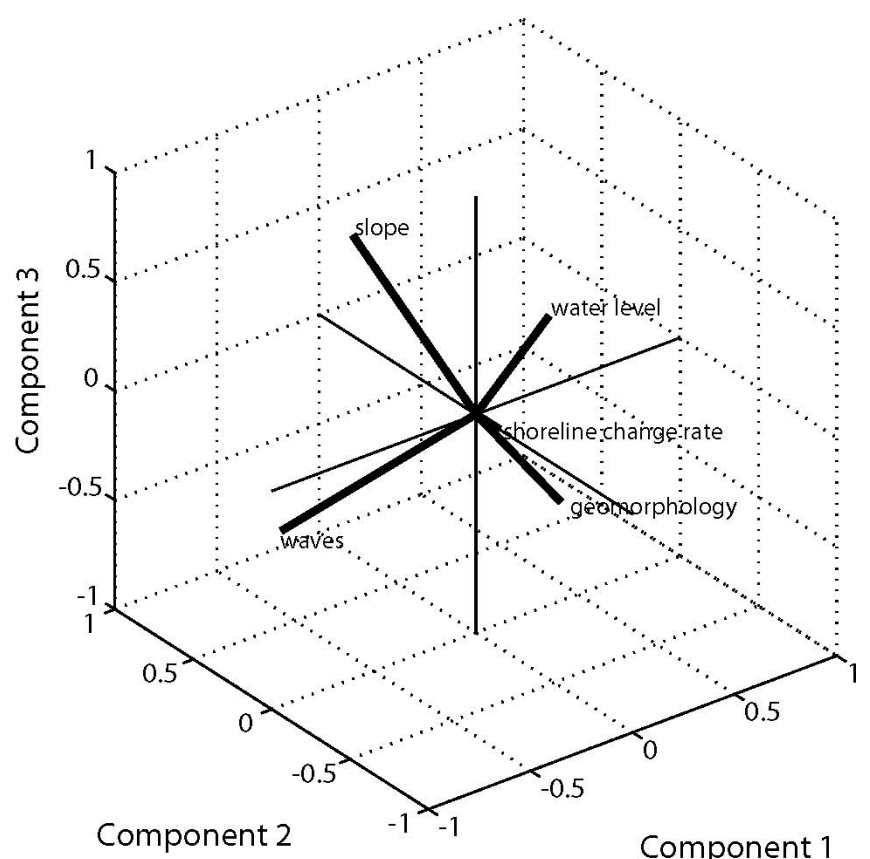

Figure 4. (A) The first four principal components (1-4), which cumulatively account for more than 99\% of the variance among the index variables. (B) Biplot of principal components 1-3. Note the short vector corresponding to shoreline change rate. The vector representing tidal range and mean annual ice cover is not visible at this scale. This suggests that tidal range (and mean annual ice cover) and shoreline change rate are not important contributors in the first three principal components.

tified an inverse relationship between: a) water-level change rate and regional coastal slope and b) mean significant wave height and regional coastal slope. These relationships make up the first principal component and account for more than half of the variability among variables. The first principal component could be interpreted as the difference between Gulf of Alaska parks and all other parks, and it may be inflating the significance of water-level change, slope, and wave heights for the entire dataset because the Alaska parks represent more than $50 \%$ of the population and their ranges vary more widely for these variables than other parks. Principal component analysis also highlights the inverse relationship between: a) geomorphology and water-level change, b) geomorphology and wave height, and c) geomorphology and coastal slope. These variable relationships represent the second principal component and account for $25 \%$ of the total variance. The third and fourth principal components account for $22 \%$ of the total variance and define relationships among the variables, geomorphology, wave height, water-level change rate, and coastal slope. Tidal range and shoreline change rate have the most significant loadings in the fifth and sixth principal components, which combined account for less than $1 \%$ of the total index variance. The relative contribution of tidal range and shoreline change to the index is less than $10 \%$ based on a com- parison of the six-variable and four-variable indices for the entire population (Figure 6B). The greatest difference in the fourvariable and six-variable indices is apparent for the Gulf of Mexico and Atlantic regions, which are represented in the first 550 samples in Figure 6B. This difference is likely a result of variability in historical shoreline change rates along sandy coastal barriers. For example, Fire Island National Seashore, an Atlantic park, experiences shoreline change rates that range from greater than $2 \mathrm{~m} / \mathrm{y}$ of erosion to greater than $2 \mathrm{~m} / \mathrm{y}$ of accretion, whereas Golden Gate National Recreation Area, a Pacific park, generally experiences between -1 to $1 \mathrm{~m} / \mathrm{y}$ of shoreline change (Pendleton, Thieler, and Williams, 2005b; Pendleton, Thieler, Williams, 2003).

Because a similar index can be derived using only four variables for a large, diverse population such as the park assessment database, the data input requirements to conduct a large scale index assessment become more manageable, especially for areas where shoreline change data may not be available. For smaller or less diverse coastal assessments, the effects of tidal range and especially shoreline change rate may be significant and should be included if feasible. In individual park assessments, historical shoreline change rate was an important variable in the first principal component for parks like Cape Hatteras National Seashore, where shore- 


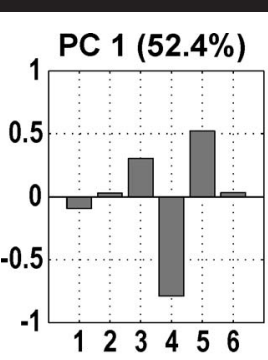

PC 2 (24.8\%)
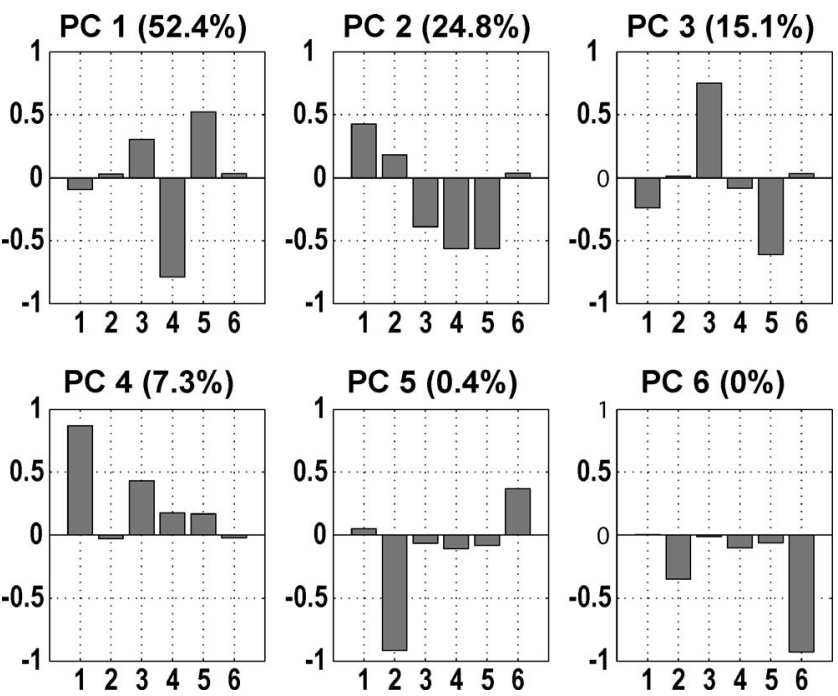

Figure 5. Bar plots of loadings within each principal component (PC) 16 ; percentage of variance explained by each component is shown in parentheses. The variables are $1=$ geomorphology; $2=$ historical shoreline change rate; 3 = regional coastal slope; $4=$ water-level change rate; $5=$ mean significant wave height; and $6=$ mean tidal range or mean annual ice cover. The percentage corresponds to the amount of variance explained by each PC.

line change rates are highly variable $(-10$ to $+10 \mathrm{~m} / \mathrm{y}$; Morton and Miller, 2005). Tidal range was an important variable in Glacier Bay National Park and Preserve, where there are large changes in tidal range $(2$ to $>4 \mathrm{~m}$ ) from the Gulf of Alaska to the upper reaches of Glacier Bay.

Often, no single variable can be considered the most important characteristic of a coast when determining vulnerability to long-term SLR. The assessment results presented here are based on a relatively simple ranking approach but include several factors that influence coastal change. These types of index assessments can serve as a first step toward understanding the characteristics of a shoreline that make it susceptible to change over the next century and illustrate that the significance of index variables can depend greatly on spatial scale.

\section{CONGLUSION}

Diversity of coastal landforms, processes, and length of shoreline examined play a role in significance of the variables used to determine coastal vulnerability. Although index results cannot be equated with a specific physical change, assessments may be used preliminarily to examine contributing factors of change and to highlight regions that may be most likely to experience water-level-related coastal change. By combining assessments of individual parks, we can examine the relative contribution of variables for more than $4400 \mathrm{~km}$ of sampled shoreline. Statistical analyses suggest that the Gulf of Mexico and the Atlantic coasts may be the most vulnerable to SLR-related coastal change. The Pacific, Great Lakes, and oceanic islands may be less vulnerable than the Atlantic and Gulf of Mexico parks. The Gulf of Alaska coastal
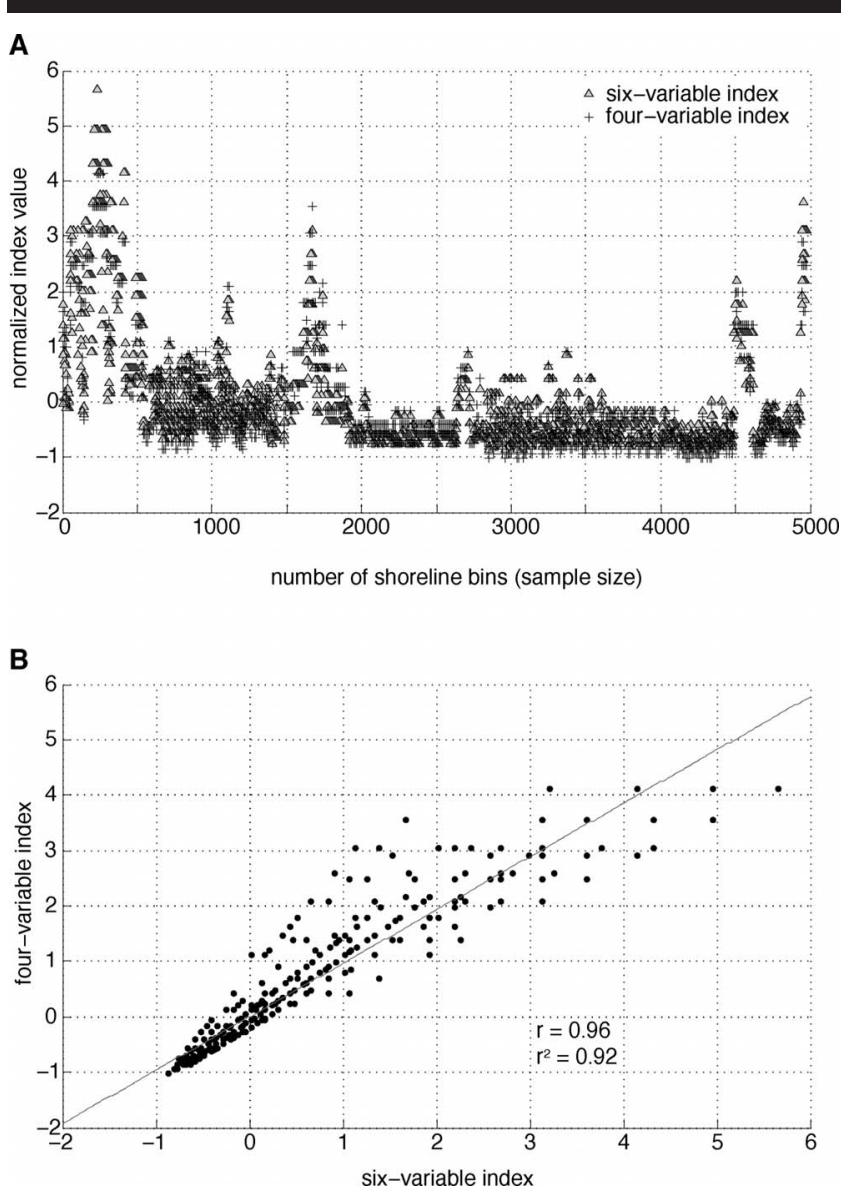

Figure 6. (A) Four-variable normalized (mean equals zero) index plotted with the six-variable normalized index to show the difference in (normalized) index values. (B) A linear regression of the six-variable index versus the four-variable index produces a correlation coefficient of 0.9635 , or $R^{2}$ of 0.9283

parks may be the least vulnerable to water-level-associated coastal change. All variables used in park assessments can be considered important factors for coastal change. Some variables make a more significant contribution to the index assessment than others. The rate of sea- or lake-level change, regional coastal slope, mean significant wave height, and geomorphology are of primary importance when conducting an assessment at a scale of thousands of kilometers. Variables such as historical shoreline change rate and tidal range are less significant for large-spatial-scale (e.g., thousands of kilometers) assessments but may play a more significant role in smaller-scale (e.g., tens of kilometers) assessments. Because these index assessments can be conducted on almost any scale and consider multiple variables that contribute to coastal change, they provide a first step to understanding coastal evolution and can aid long-term planning and decision making when properly used.

\section{ACKNOWLEDGMENTS}

The vulnerability and change potential assessments of NPS units were funded jointly by the USGS and the NPS. Rebecca 
Beavers provided the opportunity to work with the NPS on assessing the vulnerability of U.S. national parks to SLR and coastal change. We thank the numerous NPS scientists who worked with us on improving the individual park reports. We also thank Brad Butman and Jeff List of the USGS Woods Hole Science Center for constructive reviews. Comments from two anonymous reviewers were also appreciated and improved the manuscript.

\section{LITERATURE CITED}

Assel, R.A.; Quinn, F.H., and Sellinger, C.E., 2004. Hydroclimatic factors of the recent record drop in Laurentian Great Lakes water levels. Bulletin of the American Meteorological Society, 85(8), 11431151.

Austin, J.A. and Colman, S.M., 2007. Lake Superior summer water temperatures are increasing more rapidly than regional air temperatures: a positive ice-albedo feedback. Geophysical research letter, 34, doi: 10.1029/2006GL029021, L06604; 5p.

Cazenave, A. and Nerem, R.S., 2004. Present-day sea level change: observations and causes. Reviews of. Geophysics, 42(3), doi: 10 1029/2003RG000139, RG3001, 20p.

Church, J.A.; Gregory, J.M.; Huybrechts, P.; Kuhn, M.; Lambeck, K. Nhuan, M.T.; Qin, D.; Woodworth, P.L.; Anisimov, O.A.; Bryan, F.O.; Cazenave, A.; Dixon, K.W.; Fitzharris, B.B.; Flato, G.M.; Ganopolski, A.; Gornitz, V.; Lowe, J.A.; Noda, A.; Oberhuber, J.M.; O'Farrell, S.P.; Ohmura, A.; Oppenheimer, M.; Peltier, W.R.; Raper, S.C.B.; Ritz, C.; Russell, G.L.; Schlosser, E.; Shum, C.K.; Stocker, T.F.; Stouffer, R.J.; van de Wal, R.S.W.; Voss, R.; Wiebe, E.C.; Wild, M.; Wingham, D.J., and Zwally, H.J., 2001. Changes in sea level. In: Houghton, J.T.; Ding, Y.; Griggs, D.J.; Noguer, M.; van der Linden, P.J.; Dai, X.; Maskell, K., and Johnson, C.A. (eds.), Climate Change 2001: The Scientific Basis. Contribution of Working Group I to the Third Assessment Report of the Intergovernmental Panel on Climate Change. Cambridge, United Kingdom: Cambridge University Press, pp. 639-694.

Church, J.A.; White, N.J.; Coleman R.; Lambeck, K., and Mitrovica, J.X., 2004. Estimates of the regional distribution of sea-level rise over the 1950 to 2000 period. Journal of Climatology, 17, 2609-2625.

Douglas, B.C., 1997. Global sea rise: a redetermination. Surveys in Geophysics, 18, 279-292.

FitzGerald, D.M.; Fenster, M.F.; Argow, B.A., and Buynevich, I.V., 2008. Coastal impacts due to sea-level rise. Annual Review of Earth and Planetary Sciences, 36, 601-647.

Forbes, D.L.; Parkes, G.S.; Manson, G.K., and Ketch, L.A., 2004. Storms and shoreline retreat in the southern Gulf of St. Lawrence. Marine Geology, 210, 169-204.

Gornitz, V.M.; Daniels, R.C.; White, T.W., and Birdwell, K.R., 1994 The development of a coastal vulnerability assessment database: vulnerability to sea-level rise in the U.S. southeast. Journal of Coastal Research, Special Issue No. 12, pp. 327-338.

Intergovernmental Panel on Climate Change, 2001. Climate Change 2001: The Scientific Basis. Contribution of Working Group I to the Third Assessment Report of the Intergovernmental Panel on Climate Change. Cambridge, United Kingdom: Cambridge University Press, 944p. http://www.ipcc.ch/ipccreports/ar4-wg1.htm (accessed December 1, 2008).

Intergovernmental Panel on Climate Change, 2007. Climate Change 2007: The Physical Science Basis. Contribution of Working Group I to the Fourth Assessment Report of the Intergovernmental Panel on Climate Change. Cambridge, United Kingdom: Cambridge University Press, 845p. http://www.ipcc.ch/ipccreports/ar4-wg1.htm (accessed December 1, 2008).

Leuliette, E.W.; Nerem, R.S., and Mitchum, G.T., 2004. Calibration of TOPEX/Poseidon and Jason altimeter data to construct a continuous record of mean sea level change. Marine Geodesy, 27(1 \& 2), 79-94.

Meehl, G.A.; Stocker, T.F.; Collins, W.D.; Friedlingstein, P.; Gaye, A.T.; Gregory, J.M.; Kitoh, A.; Knutti, R.; Murphy, J.M.; Noda, A.;
Raper, S.C.B.; Watterson, I.G.; Weaver A.J., and Zhao, Z.C., 2007. Global climate projections. In: Solomon, S.; Qin, D.; Manning, M.; Chen, Z.; Marquis, M.; Averyt, K.B.; Tignor, M., and Miller, H.L. (eds.), Climate Change 2007: The Physical Science Basis. Contribution of Working Group I to the Fourth Assessment Report of the Intergovernmental Panel on Climate Change. Cambridge, United Kingdom: Cambridge University Press, pp. 747-845.

Miller, L. and Douglas, B.C., 2004. Mass and volume contributions to twentieth-century global sea level rise. Nature, 428, 406-409.

Morton, R.A. and Miller, T., 2005. National Assessment of Shoreline Change: II. Historical Shoreline Changes and Associated Coastal Land Loss along the U.S. Southeast Atlantic Coast. U.S. Geological Survey Open-File Report 2005-1401. http://pubs.usgs.gov/of/ 2005/1401 (accessed December 1, 2008).

Nicholls, R.J.; Wong, P.P.; Burkett, V.R.; Codignotto, J.O.; Hay, J.E.; McLean, R.F.; Ragoonaden, S., and Woodroffe, C.D., 2007. Coastal systems and low-lying areas. In: Parry, M.L., Canziani, O.F.; Palutikof, J.P.; van der Linden, P.J., and Hanson, C.E. (eds.), Climate Change 2007: Impacts, Adaptation and Vulnerability. Contribution of Working Group II to the Fourth Assessment Report of the Intergovernmental Panel on Climate Change Parry. Cambridge, United Kingdom: Cambridge University Press, pp. 315-356.

Peltier, W.R., 2001. Global glacial isostatic adjustment and modern instrumental records of relative sea level history. In: Douglas, B.C.; Kearney, M.S., and Leatherman, S.P. (eds.), Sea-level Rise: History and Consequences. San Diego: Academic Press, pp. 65-95.

Pendleton, E.A.; Thieler, E.R., and Williams, S.J., 2005a. Coastal Vulnerability Assessment of National Park of American Samoa to SeaLevel Rise. U.S. Geological Survey Open-File Report 2005-1055. http://pubs.usgs.gov/of/2005/1055 (accessed December 1, 2008).

Pendleton, E.A.; Thieler, E.R., and Williams, S.J., 2005b. Coastal Vulnerability Assessment of Golden Gate National Recreation Area to Sea-Level Rise. U.S. Geological Survey Open-File Report 2005-1058. http://pubs.usgs.gov/of/2005/1058 (accessed December 1, 2008).

Pendleton, E.A.; Thieler, E.R., and Williams, S.J., 2007. Coastal Change-Potential Assessment of Sleeping Bear Dunes, Indiana Dunes, and Apostle Islands National Lakeshores to Lake-Level Changes. U.S. Geological Survey Open-File Report 2005-1249. http://pubs.usgs.gov/of/2005/1249 (accessed December 1, 2008).

Pendleton, E.A.; Williams, S.J., and Thieler, E.R., 2003. Coastal Vulnerability Assessment of Fire Island National Seashore to SeaLevel Rise. U.S. Geological Survey Open-File Report 03-439. http://pubs.usgs.gov/of/2003/of03-439 (accessed December 1, 2008).

Pendleton, E.A.; Hammar-Klose, E.S.; Thieler, E.R., and Williams, S.J., 2003. Coastal Vulnerability Assessment of Gulf Islands National Seashore to Sea-Level Rise. U.S. Geological Survey OpenFile Report 03-108. http://pubs.usgs.gov/of/2003/of03-108 (accessed December 1, 2008).

Rahmstorf, S.; Cazenave, A.; Church, J.A.; Hansen, J.E.; Keeling, R.F.; Parker, D.E., and Somerville, R.C.J., 2007. Recent climate observations compared to projections. Science, 316, 709.

Rahmstorf, S., 2007. A semi-empirical approach to projecting future sea-level rise. Science, 315, 368.

Shaw, J.; Taylor, R.B.; Forbes, D.L.; Ruz, M.H., and Solomon, S., 1998. Sensitivity of the Canadian coast to sea-level rise. Geological Survey of Canada Bulletin, 505, 114p.

Thieler, E.R. and Hammar-Klose, E.S., 1999. National Assessment of Coastal Vulnerability to Sea-Level Rise, U.S. Atlantic Coast. U.S. Geological Survey Open-File Report 99-593, 1 sheet.

U.S. Geological Survey, Woods Hole Science Center, 2005. Relative Coastal Vulnerability Assessment of National Park Units to SeaLevel Rise. http://woodshole.er.usgs.gov/project-pages/nps-cvi (accessed October 20, 2008).

U.S. Global Change Research Program, 2000. The Potential Consequences of Climate Variability and Change: Great Lakes Overview. Washington, DC: U.S. Climate Change Science Program, the U.S. Global Change Research Program, and the U.S. Environmental Protection Agency, 106p.

Zervas, C., 2001. Sea-Level Variations of the United States, 1854-1999. National Ocean Service Technical Report NOS CO-OPS 36. Silver Springs, Maryland: National Atmospheric Administration, 201p. 